\title{
THE CONCEPT OF MONITORING BLADES OF ROTOR MACHINES WITH THE IDENTIFICATION OF THEIR VIBRATION FREQUENCY
}

\section{KONCEPCJA MONITOROWANIA LOPATKI MASZYNY WIRNIKOWEJ Z IDENTYFIKACJĄ JEJ CZESTOTLIWOŚCI DRGAŃ}

\author{
Edward Rokicki, Pawel Lindstedt, \\ Jerzy Manerowski, Jarosław Spychała
}

Air Force Institute of Technology, Instytut Techniczny Wojsk Lotniczych

\begin{abstract}
The paper presents the basis of a new method for monitoring the technical condition of rotating blades during their operation. Utilizing the measurement of blade tip instantaneous speed under subsequent sensors, enables direct determination of the blade vibration frequency. The method utilizes a diagnostic model in the form of amplitude amplification $\boldsymbol{W}_{i j}{ }_{i j}$ and phase shift $\boldsymbol{\varphi}_{i j}$ of a diagnostic signal $y(t)$ resulting from the operation of the blade and the signal $x(t)$ from its environment, when the blade tip passes under a cascade of blade tip instantaneous speed sensors. The adopted diagnostic model, indirectly takes into account the current surrounding of a blade $x(t)$ without the need to measure it [12, 14]. Evaluation of the blade technical condition in real time and static analysis shall be performed on the basis of the vibration process parameter analysis. The suggested method may play an important role in the diagnostics of rotor machine blades during their operation.
\end{abstract}

Keywords: blade diagnostics, correlation function, spectral power density function, amplitude strengthening, phase sift, instantaneous amplitude of vibration velocity, blade vibration displacement amplitude.

Streszczenie: $W$ artykule przedstawiono podstawy nowej metody monitorowania stanu technicznego topatek maszyn wirnikowych podczas ich użytkowania. Wykorzystując pomiar chwilowej prędkości wierzchołka topatki pod kolejnymi czujnikami kaskady umożliwia się bezpośrednie wyznaczenie częstotliwości drgań topatki. Metoda wykorzystuje model diagnostyczny $w$ postaci wzmocnienia amplitudowego $\boldsymbol{W}_{i j}^{2} i$ przesunięcia fazowego $\boldsymbol{\varphi}_{i j}$ sygnatu diagnostycznego $y(t)$ wynikajacego $z$ działania topatki $i$ sygnatu $x(t)$ jej otoczenia podczas przechodzenia wierzchołka topatki pod kaskada czujników prędkości chwilowej wierzchotka topatki. Przyjęty model diagnostyczny pośrednio uwzględnia aktualne otoczenie topatki $x(t)$ bez konieczności jego pomiaru [12, 14]. Na podstawie analizy parametrów procesu drganiowego dokonywana będzie ocena stanu technicznego topatki $w$ czasie rzeczywistym oraz analiza statystyczna. Proponowana metoda może odegrać istotna role $w$ diagnostyce topatek maszyn wirnikowych podczas ich użytkowania.

Stowa kluczowe: diagnostyka topatki, funkcja korelacji, funkcja widmowej gęstości mocy, wzmocnienie amplitudowe, przesunięcie fazowe, chwilowa amplituda prędkości drgań, amplituda przemieszczenia drgań topatki. 
The concept of monitoring blades of rotor machines with the identification... Koncepcja monitorowania topatki maszyny wirnikowej z identyfikacja...

\section{THE CONCEPT OF MONITORING BLADES OF ROTOR MACHINES WITH THE IDENTIFICATION OF THEIR VIBRATION FREQUENCY}

\section{Introduction}

In the course of the operation (work) process of rotor machines, it is extremely important to monitor (current evaluation) of the technical condition of their critical components, namely, bearings and blades. Practice shows that snapping of just one blade (out of a few dozen or hundred), almost always leads to a serious failure (often very costly) of the entire rotor machine (axial compressor, turbine). Hence, the great interest in methods of continuous monitoring of the blade technical condition during their operation.

Currently, many different methods for monitoring the technical condition of rotor machine blades are utilized. These methods are based on the so-called "noncontact" estimation of current displacement values of the blade tip when it is in the area under a sensor. Many "non-contact" measurement systems (with specialized computer software) were developed for monitoring and processing blade operation signals during operation of a rotor machine. They are widely known and applied measuring systems, made by the following companies: Hood, Agilis, Prat\&Whithey (USA), Rolls Royce (UK), ABB Turbocharges (Switzerland), MTU (Germany), ITWL (Poland), as well as Russian, Chinese and Indian companies $[1,3,4,5,6,7,8,9,10,11,16,18,19,20]$.

The previous blade technical condition monitoring methods are based only on processing measured signals arising from the blade operation, without sufficiently taking into account the changing environment, which, most probably, results from the fact that the measurement of the blade's changing environment (variables: temperature, pressure, centrifugal forces, bending and torsional moments; forces securing a blade in the lock) is very difficult and often impossible. Therefore, it needs to be said that these methods do not fully implement the basic rule of technical diagnostics which orders testing and analysis of an object's technical condition taking into account the environmental impact, which is why, they cannot be considered as sufficiently accurate.

The previously suggested diagnostic methods do not directly translate to basic, measurable parameters of the vibration process. Therefore, the need to develop a new method for monitoring the condition of the blades in real time, which takes into account their environment, however, without measuring the inaccessible, often unmeasurable ambient signals.

This issue is currently being solved by double, identical stimulation of the blade and putting it into vibration (static diagnostics) $[12,14]$ or studying the blade tip movement in two, different observation periods (dynamic diagnostics) $[5,6,15]$. 
This is why a new blade technical condition monitoring method during operation was developed, which is based on measuring the movements of the blade tip with a cascade consisting of 3 induction sensors of instantaneous speed (sufficiently little shifted in relation to each other).

This method provides wide possibilities of determined and static analysis, leading to the determination of the basic vibration process parameter, the blade vibration frequency, which allows to define the changes of the blade technical condition.

\section{Blade during operation in a variable environment}

A blade during operation in a variable environment was presented in Fig. 1.
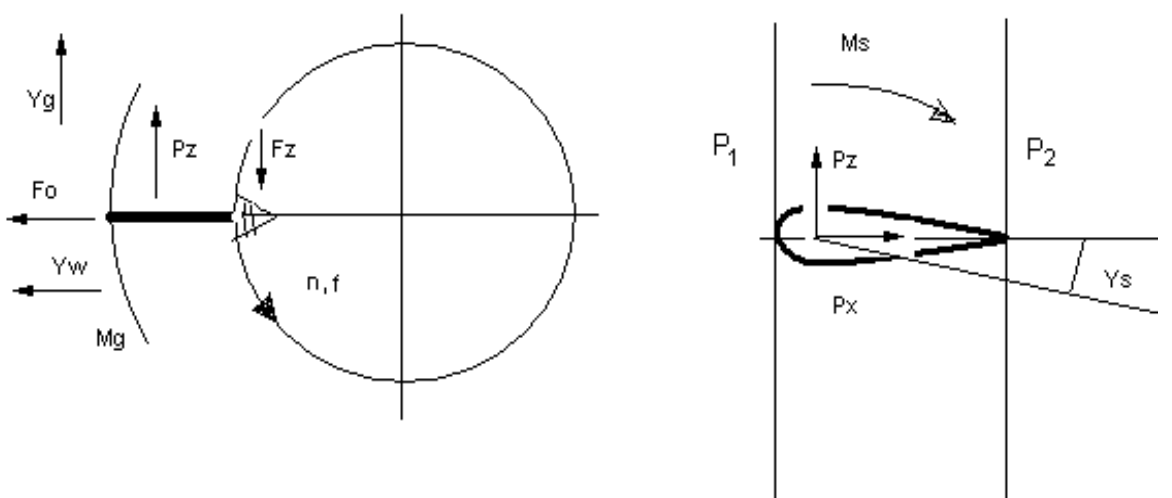

Fig. 1 A rotor machine blade in a variable environment.

$F_{o}$ - centrifugal force; $F_{z}$ - lock clamping force; $n$ - rotating speed;

$P_{z}$ - aerodynamic lifting force of the blade; $P_{x}$ - resistance force; $M_{s}$ - torsional moment; $M_{g}$ - bending moment; $p_{1}$ - gas pressure on the rotor crown inlet; $\mid p_{2}-$ gas pressure on the rotor crown outlet; $Y_{g}$ - blade deflection; $Y_{s}$ - blade torsion angle; $Y_{w}$-blade longitudinal displacement; $f$ - signal of different vibration forms (torsional, bending, longitudinal)

Fig. 1. indicates that a blade is a relatively simple technical object in terms of the structure, however, with a complex operating state, present in a multidimensional, variable environment. The blade operating states describes a measurable blade tip displacement signal $y(t)$, which is the result of signal activity $\left(Y_{g}, Y_{w}, Y_{s}, f\right)$, and its environment is defined by a multidimensional signal $x(t)$, which is the result of the activity of signals $\left(n, F_{0}, P_{z}, P_{x}, p_{1}, p_{2}, F_{z}, f\right)$. The technical state of blade $A(\Theta)$ results from the relationship between signal $y(t)$ and $x(t)$ at the moment of the currently diagnosed $\Theta_{1}$ and at the beginning of the diagnosed $\Theta_{0}$.

Therefore, it can be noted [13, 15]: 
The concept of monitoring blades of rotor machines with the identification... Koncepcja monitorowania topatki maszyny wirnikowej z identyfikacja...

$$
A(\Theta)=f\left(y(t)_{\Theta_{0}}, x(t)_{\Theta_{0}}, y(t)_{\Theta_{1}}, x(t)_{\Theta_{1}}\right.
$$

where:

$A(\Theta)$ - parameter matrix of the blade technical condition,

$\mathrm{t} \quad$ - Newtonian time (diagnostic tests),

$\Theta \quad-$ Bergsonian time (diagnostic conclusions).

The coefficients, which characterize the technical condition of blade $A(\Theta)$ and deterministic signals $y(t)$ and signal $x(t)$ after transformation, are present in the form of spectral transmittance:

$$
G(j \omega)=\frac{Y(j \omega)}{X(j \omega)}=\frac{\sum_{i=0}^{m} b_{i}(j \omega)^{i}}{\sum_{i=0}^{n} a_{i}(j \omega)^{i}}=\frac{S_{x y}}{S_{x x}}
$$

And in the function determining the square of amplitude amplification $W^{2}$ and phase shift $\varphi$ of signal $y(t)$ relative to the ambient signal $x(t)$ :

$$
\begin{gathered}
\varphi=\operatorname{Arg} G(j \omega)=\operatorname{Arg} \frac{\sum_{i=0}^{m} b_{i}(j \omega)^{i}}{\sum_{i=0}^{m} a_{i}(j \omega)^{i}}=\operatorname{Arg} \frac{S_{x y}}{S_{x x}} \\
W^{2}=|G(j \omega)|^{2}=\frac{\sum_{i=0}^{m} b_{i}(j \omega)^{i}}{\sum_{i=0}^{n} a_{i}(j \omega)^{i}}=\left|\frac{S_{x y}}{S_{x x}}\right|^{2}=\frac{S_{y y}}{S_{x x}}
\end{gathered}
$$

where:

$G(j \omega) \quad-$ spectral transmission,

(j $\omega) \quad-$ complex variable imaginary frequency $s$,

$S_{x y}, S_{y y}, S_{x x} \quad-\quad$ self and cross spectral density functions of the power of signals $y(t)$ and $x(t)$.

Mathematical expressions (3) and (4) may be diagnostic models of the tested technical object. Because they bind the operating signals of object $y(t)$ and ambient signals $x(t)$ with the parameters of the technical condition $A(\Theta)[2,12$, $14,15,16,17]$.

The suggested solution for the measuring system involves three measuring sensors, placed at a short distance from each other $\Delta L$. Therefore, we have: 


$$
\begin{gathered}
W_{(1)}^{2}=\frac{S_{y y}^{(1)}}{S_{x x}^{(1)}} ; \quad W_{(2)}^{2}=\frac{S_{y y}^{(2)}}{S_{x x}^{(2)}} ; \quad W_{(3)}^{2}=\frac{S_{y y}^{(3)}}{S_{x x}^{(3)}} \\
\varphi_{(1)}=\operatorname{Arg} \frac{S_{x y}^{(1)}}{S_{x x}^{(1)}} ; \varphi_{(2)}=\operatorname{Arg} \frac{S_{x y}^{(2)}}{S_{x x}^{(2)}} ; \quad \varphi_{(3)}=\operatorname{Arg} \frac{S_{x y}^{(3)}}{S_{x x}^{(3)}}
\end{gathered}
$$

Due to the fact that the sensors are placed only a short distance from each other, it can be assumed that the environment represented by signals $x(t)$ is constant, which gives us;

$$
S_{x x}^{(1)}=S_{x x}^{(2)}=S_{x x}^{(3)} .
$$

Next, we can create new diagnostic models which are independent from the environment, in the form of relative quotients of amplitude amplifications;

$$
\begin{aligned}
& W_{(1,2)}^{2}=\frac{\frac{S_{y_{1} y_{1}}^{(1)}}{S_{x_{1} x_{1}}^{(1)}}}{\frac{S_{y_{y_{2}} y_{2}}^{(2)}}{S_{x_{2} x_{2}}^{(2)}}}=\frac{S_{y_{y_{1}}}^{(1)}}{S_{y_{2} y_{2}}^{(2)}} \\
& W_{(2,3)}^{2}=\frac{\frac{S_{y_{2} y_{2}}^{(2)}}{S_{x_{2} x_{2}}^{(2)}}}{\frac{S_{y_{y_{3}}}^{3}}{S_{x_{3} x_{3}}^{(3)}}}=\frac{S_{y_{2} y_{2}}^{(2)}}{S_{y_{3} y_{3}}^{(3)}} \\
& \Delta \varphi_{(1,2)}=\operatorname{Arg} \frac{\frac{S_{x_{1} y_{1}}^{(1)}}{S_{x_{1} x_{1}}^{(1)}}}{S_{x_{2} y_{2}}^{(2)}}=\operatorname{Arg} \frac{A_{2}^{(2)} e^{-j \varphi_{2}}}{S_{x_{2} x_{2}}^{(1)}} e^{-j \varphi_{1}}=\operatorname{Arg} \frac{A_{2}^{(2)}}{A_{1}^{(1)}} e^{-j\left(\varphi_{2}-\varphi_{1}\right)}=\operatorname{Arg} \frac{S_{x_{1} y_{1}}^{(1)}}{S_{x_{2} y_{2}}^{(2)}} \\
& \Delta \varphi_{(2,3)}=\operatorname{Arg} \frac{\frac{S_{x_{2} y_{2}}^{(2)}}{S_{x_{2} x_{2}}^{(2)}}}{\frac{S_{x_{3} y_{3}}^{(3)}}{S_{x_{3} x_{3}}^{(3)}}}=\operatorname{Arg} \frac{A_{2}^{(2)} e^{-j \varphi_{2}}}{A_{3}^{(3)} e^{-j \varphi_{3}}}=\operatorname{Arg} \frac{A_{2}^{(2)}}{A_{3}^{(3)}} e^{-j\left(\varphi_{3}-\varphi_{1}\right)}=\operatorname{Arg} \frac{S_{x_{2} y_{2}}^{(2)}}{S_{x_{3} y_{3}}^{(3)}}
\end{aligned}
$$

$W_{(12)}^{2}$ - amplitude amplification from the sensor 1 signal relative to sensor 2 signal

$S_{y_{1} y_{1}}^{(1)} S_{y_{2} y_{2}}^{(2)}$ - self spectral density of the y signal power from sensor 1 and sensor 2

$S_{x_{1} x_{1}}^{(1)} S_{x_{2} x_{2}}^{(2)}$ - self spectral density of the x ambient signal power from sensor 1 and sensor 2 
The concept of monitoring blades of rotor machines with the identification... Koncepcja monitorowania łopatki maszyny wirnikowej z identyfikacja...

$W_{(23)}^{2}$ - amplitude amplification from the sensor 2 signal relative to sensor 3 signal

$S_{y_{3} y_{3}}^{(3)} S_{y_{2} y_{2}}^{(2)}$ - self spectral density of the y signal power from sensor 3 and sensor 2

$S_{x_{2} x_{2}}^{(3)} S_{x_{2} x_{2}}^{(2)}$ - self spectral density of the $\mathrm{x}$ ambient signal power from sensor 3 and sensor 2

$\Delta \varphi_{(1,2)}=\varphi_{(1)}-\varphi_{(2)}-$ signal phase shift difference relative to signal $\mathrm{x}$ from sensor (1) and (2)

$\Delta \varphi_{(2,3)}=\varphi_{(3)}-\varphi_{(2)}-$ signal phase shift difference relative to signal $\mathrm{x}$ from sensor (3) and (2)

$S_{x y}^{(2)} S_{x y}^{(3)}$ - cross-spectral density of the y signal power from sensor 2 and sensor 3 and their environment $\mathrm{x}$.

Models $7 \div 10$ have a feature that they do not require measurement of environment $\mathrm{x}$. Formulas 9 and 10 contain the environment $\mathrm{x}$ signal but it can be a randomly adopted distribution $\boldsymbol{\delta}(\boldsymbol{t}, \boldsymbol{\tau})$ since the product of cross-spectral densities of signals $\mathrm{x}$ and $\mathrm{y}$ does not depend on the form of signal $\mathrm{x}[2,5,17]$

\section{The method of monitoring the blade technical condition on the basis of observing frequencies from expressions $W_{i j}^{2}$ and $\varphi_{i j}$}

A method of monitoring the changes of rotor machine blade technical conditions based on the observation of frequency calculated from the expressions $\boldsymbol{W}_{\boldsymbol{i} \boldsymbol{j}}^{2}$ and $\varphi_{i j}$ , determined during the passing of a blade under three successive sensors. Their distinguishing feature is that a fixed movement time, for example $T_{(1)}$ fig. 2. of blade $y(t)$ under sensor (1) is known and allows to determine the instantaneous speed of the blade movement under the sensor. In the same manner, we shall determine instantaneous blade movement speeds under subsequent sensors (2) and (3). An example of a signal created during the blade movement under a sensor wit different times of observation $T_{d}$ and $T_{(1)}$ are presented in fig. 2.

Fig. 3 presents actual signals from the induction sensors of a cascade for successive blades of a steam turbine and signals from a cascade for a selected, single blade. Fig. 4 presents selected signals from 3 sensors of a cascade for a selected blade and the same signals after normalization. 
Edward Rokicki, Pawet Lindstedt, Jerzy Manerowski, Jarosław Spychata

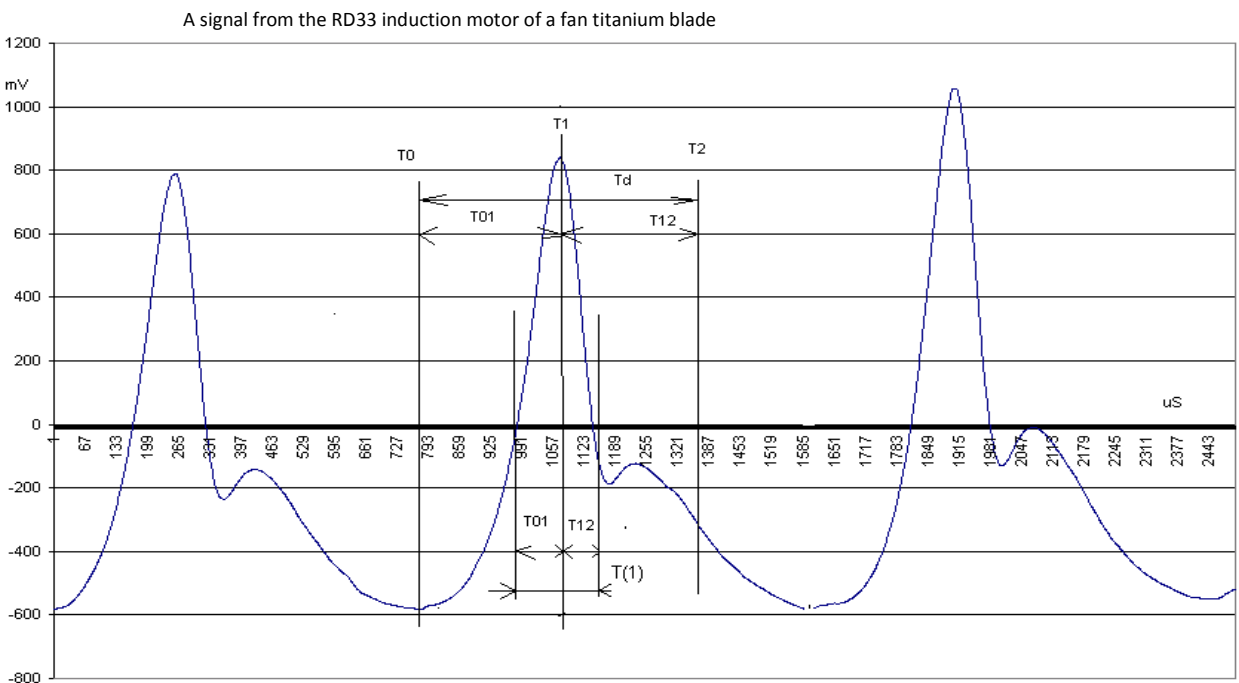

Fig. 2 A signal from an induction sensor of passing blades

$T_{d},-$ long observation interval of the blade tip presence in the sensor area, $T_{(1)}-$ short observation interval of the blade tip presence in the sensor area, for successive sensors $T_{(2)} T_{(3)}$,

$T_{0}, T_{1}, T_{2}$ - characteristic observation moments for the blade tip under a sensor, $T_{01}, T_{12}$ - blade tip observation sub-intervals

- blade tip movement signal - $m V$,

- blade movement time - uS

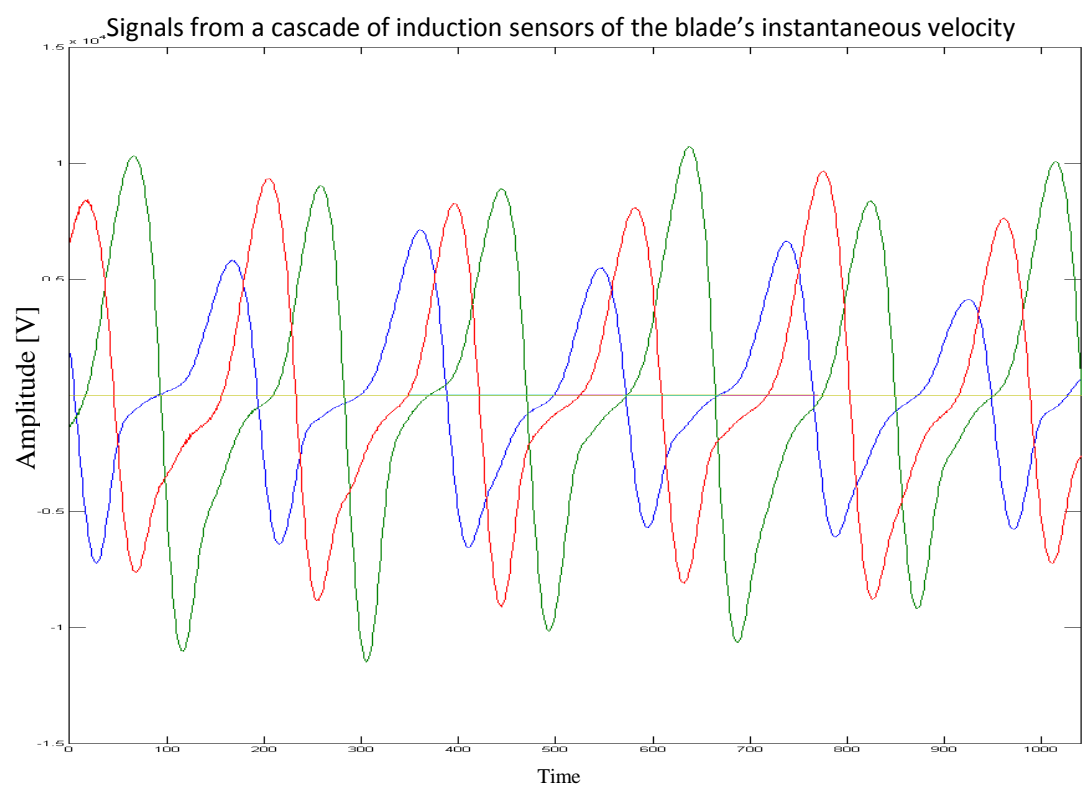

Fig. 3 Actual signals from a sensor cascade of a rotor machine 
The concept of monitoring blades of rotor machines with the identification... Koncepcja monitorowania łopatki maszyny wirnikowej z identyfikacja...
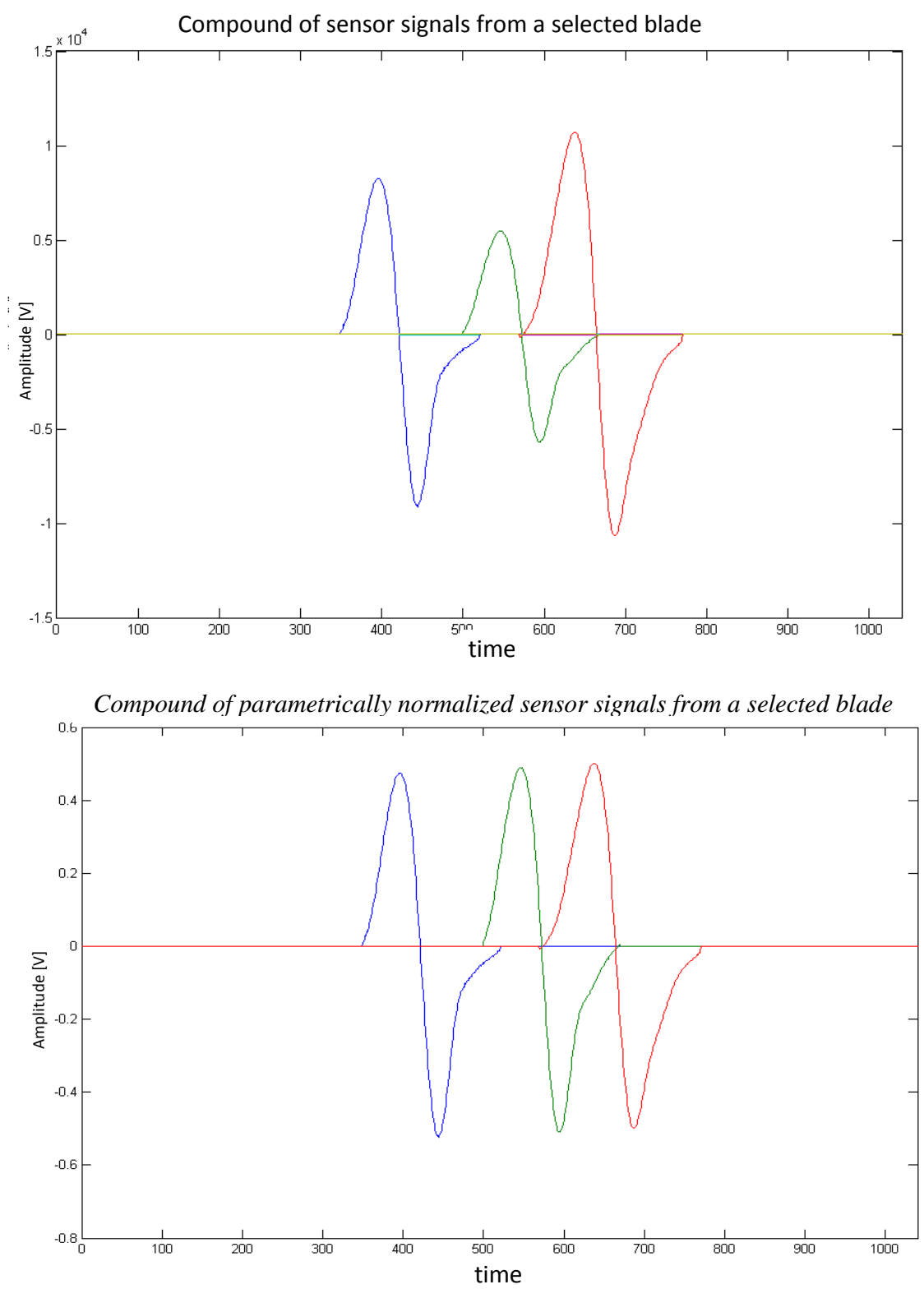

Fig. 4 Selected actual signals from a sensor cascade of a rotor machine and signals after parametric calibration

Next, for signals $y_{(1)}(t), y_{(2)}(t), y_{(3)}(t)$ withintime adopted observation intervals $T_{(1)}, T_{(2)}, T_{(3)}$ we determine the estimates of the autocorrelation function $R_{y_{1} y_{1}}$

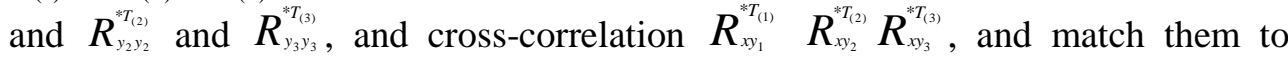
relevant analytic expressions $[2,12,13,14,17]$ : 
- for sensors 1,2, 3, we have:

$$
\boldsymbol{R}_{y_{k} y_{k}}^{(k) T_{(k)}} \cong \sum_{i=0}^{m} \alpha_{i T_{(k)}} e^{-\beta \pi_{(k)} \tau} \cos \left(\gamma_{\pi_{(k)}} \tau\right)
$$

where:

$\mathrm{k}=(1),(2),(3)$ next sensor

$\alpha_{i T_{(1)}} \beta_{T T_{(1)}} \gamma_{i T_{(1)}}$ - parameters of the analytic form of the correlation function,

$\tau$ - shift time (a variable of the correlation function space),

$\mathrm{m}$ - number of components of the correlation function.

Cross-correlation function of the output signal $y(t)$ with the output signal distribution $x(t)=\delta(t, \tau)$

$$
\boldsymbol{R}_{\delta \delta_{(k)}}^{(k) T_{k}}=\sum_{i=0}^{m} \alpha_{i T_{(k)}} e^{-\beta_{T_{(k)}} \tau} \cos \left(\gamma_{i_{(k)}} \tau\right)
$$

where:

$\alpha_{i T_{(k)}} \beta_{i T_{(k)}} \gamma_{i T_{(k)}}$ - parameters of the analytic form of the correlation function and the next sensor

$\tau$ - shift time (different from the dynamic time $\mathrm{t}$ )

$m$ - number of components of the correlation function.

Correlation functions $R_{y_{x_{k}}}^{(k)_{k_{k}}}$ and $\boldsymbol{R}_{\delta_{\delta_{k}}}^{(k)}$ are the basis for the determination of the signal power density function for subsequent sensors

$$
\begin{aligned}
S_{y_{k} y_{k}}^{k} & =\mathfrak{J} R_{y_{y_{1} y_{k}}^{(k) T_{k}}}^{(k)} \\
S_{\partial y_{k}}^{k} & =\mathfrak{J} R_{\partial y_{k}}^{(k)}
\end{aligned}
$$

where $\mathrm{k}$ is the number of the next sensor.

Expressions [11] and [12] allow to determine $W_{(12)}^{2} W_{(23)}^{2} \Delta \varphi_{(12)} \Delta \varphi_{(23)}$ (formulas $7 \div 10$ ) which are reduced to algebraic form

$$
\begin{gathered}
W_{(12)}^{2}=\frac{S_{y_{y, 2}}^{(1)}}{S_{y_{2}, y_{2}}^{(2)}}=\frac{\sum_{i=0}^{m} b_{i}^{(1.2)}(s)^{i}}{\sum_{i=0}^{n} a_{i}^{(1,2)}(s)^{i}} \\
W_{(23)}^{2}=\frac{S_{y_{2, y_{2}}}^{(2)}}{S_{y_{3, y_{3}}}^{(3)}}=\frac{\sum_{i=0}^{m} b_{i}^{(2,3)}(s)^{i}}{\sum_{i=0}^{i} a_{i}^{(2.3)}(s)^{i}} \\
\Delta \varphi_{(12)}=\operatorname{Arg} \frac{S_{\delta, y_{2}}^{(2)}}{S_{\delta, y_{1}}^{(1)}}=\operatorname{Arg} \frac{\sum_{i=0}^{m} L_{n}^{(1,2)}(s)^{i}}{\sum_{i=0}^{n} M_{i}^{(1,2)}(s)^{i}}
\end{gathered}
$$


The concept of monitoring blades of rotor machines with the identification... Koncepcja monitorowania topatki maszyny wirnikowej z identyfikacja...

$$
\Delta \varphi_{(23)}=\operatorname{Arg} \frac{S_{\delta, y_{3}}^{(3)}}{S_{\delta, y_{2}}^{(2)}}=\operatorname{Arg} \frac{\sum_{i=0}^{m} L_{i}^{(2,3)}(s)^{i}}{\sum_{i=0}^{n} M_{i}^{(2,3)}(s)^{i}}
$$

While $s \equiv j \omega \quad \omega$ - the blade vibration frequency between successive sensors Small distances between sensors 1, 2, 3 were structurally secured. Therefore, it was previously assumed that $X_{1}(t)=X_{2}(t)=X_{3}(t)$ is constant.

On the basis of the close location of sensors 1 and 2, and 2 and 3, it can be also assumed that:

$$
\begin{gathered}
\frac{W_{(12)}^{2}}{W_{(23)}^{2}} \cong 1 \\
\Delta \varphi_{(1,2)}-\Delta \varphi_{(2,3)} \cong 0
\end{gathered}
$$

It means that the amplitude amplification between sensors 1 and 2, and 2 and 3 is constant. The phase shift increment is also constant. Formulas 17 and 18 enable the determination of the vibration frequencies of blade $\omega$ between sensors 1 and 2, and 2 and 3 .

\section{Conclusions}

The method for monitoring the changes of the blade technical condition is an innovative diagnostic method for blades in an environment without ambient signals measurement.

The blade technical condition monitoring method is based on a diagnostic model in the form of a product of amplitude amplifications $W_{(12)}^{2}$ and $W_{(23)}^{2}$ of phase shifts $\Delta \varphi_{(12)}$ and $\Delta \varphi_{(23)}$ of the output signal $y(t)$ to the ambient signal $x(t)$ for sensors (1), (2), (3) arranged close to each other.

The object technical condition monitoring method is characterized by the fact that the amplitude amplification $W^{2}$ and the phase shift between sensors do not change (formulas 17 and 18). The characteristic feature of model $W^{2}$ and $\Delta \varphi$ is also the fact that it does not require ambient signal measurement, although it is indirectly taken into account by specially organized diagnostic tests (several observation periods, several excitations, few sensors, determination of a diagnostic model as a product of diagnostic models binding ambient signals with the technical condition parameters). The main diagnostic parameter in this method is the blade vibration frequency at a given time of blade observation. 


\section{Bibliography}

[1] Bovishanskii K.N. et.al.: A method for continuously monitoring the vibrational state of the rotating blades of turbomachines. Thermal engineering (Teploenegetika), Vol 47 No 5 2000. St. Petersburg

[2] Bendat J.S., Piersol A.G.: Metody analizy i pomiaru sygnałów losowych. [Methods of analysing and measuring random signals] PWN, Warszawa 1976

[3] Duan F., Fang Z., Sun Y., Ye S.: Real-time vibration measurement technique based on tip - timing for rotating blades. Opto-Electronic Energineering 200530 (1) 29-31 htt://www.paper.edu.cn

[4] von Flotow A., Mercadal H.: Turbine rotor health management with bladetip sensors; From Laboratory Tool To Fielded System. www hoodtech tlood River or USD 2000

[5] Grądzki R. Parametryczne modele diagnostyczne łopatki pracującej maszyny wirnikowej $\mathrm{z}$ eliminacją niemierzalnych sygnałów otoczenia. [Parametric diagnostic models of a blade in an operating rotor machine, with the elimination of unmeasurable ambient signals] Rozprawa doktorska. [Doctoral dissertation] Politechnika Białostocka Białystok 2012

[6] Grądzki R. Borowczyk H. Lindstedt P. Parametryczna metoda diagnozowania maszyny wirnikowej z eliminacją niemierzalnych czynników otoczenia. Tom 8. Problemy Badań I Eksploatacji Techniki Lotniczej. [Parametric method of diagnosing a rotor machine with the elimination of unmeasurable ambient factors. Volume 8. Issues of Studying and Applying Aviation Techniques] Wyd. ITWL Warszawa 2012

[7] High Cycle Fatigue S \& program 1999 Annual Report http://stimet.dtic.mil

[8] High Cycle Fatigue S \& program 2000 Annual Report http://stimet.dtic.mil

[9] High Cycle Fatigue S \& program 2001 Annual Report http://stimet.dtic.mil

[10] High Cycle Fatigue S \& program 2002 Annual Report http://stimet.dtic.mil

[11] Klein B.: Non-Contact Vibration measurements Turbocharges Turbine and Compressor Blades. Proceedings of $1^{\text {st }}$ EVI-GTI International Conference on Gas Turbine Instrumentation, Barcelona 2004

[12] Kotowski A., Lindstedt P.: The use of signals of impulse acoustic response in tests of rotor blades in stationary conditions. The International Symposium on Stability Control of Rotating Machinery. ISCORMA 4, Calgary Alberta Canada 2007

[13] Kurowski W.: Podstawy teoretyczne komputerowego miernictwa systemów mechanicznych. [Theoretical basis of computer based measurements of mechanical systems] Wyd. Politechniki Białostockiej, Białystok 1994 
The concept of monitoring blades of rotor machines with the identification... Koncepcja monitorowania łopatki maszyny wirnikowej z identyfikacja...

[14] Lindstedt P., Kotowski A.: Basics for innovations in vibroacoustic diagnostics of transport machines rotor blades. The Archives of Transport Vd XVI No4 2004

[15] Lindstedt P. Grądzki R. : Diagnosis in a working rotor machine employing the method virtual elimination of statistic environment. The Archive of Mechanical Engineering. Vol LVIII2013,3 Warsaw.

[16] Roberts J.P.: Comparison of Tip Timing with strain ganges for rotor blade vibration measurement. Proceedings of lecture series on Tip Timing an Tip Clearnce Problems in Turbomachines Von Karman Instytute Belgium 2007

[17] Szabatin J.: Podstawy teorii sygnałów [The basics of the theory of signals], WKŁ Warszawa 2000,

[18] Szczepanik R., Przysowa R.: Wykonanie badań i pomiarów drgań łopatek metodą bezstykową w odwirowni ALSTOM Power w Elblągu. [Studies and measurements of blade vibrations with a non-contact method in the ALSTOM rotor balancing facility in Elblag] Sprawozdanie ITWL nr 36/3 /2004 Warszawa 2004

[19] Washburn R. S.: A State of The Art PC based NSMS Analysis Software Package. http;//www.agilismeasurementsystems.com

[20] Zieliński M., Ziller G.: Non-contact Blade Vibration measurement system for aero engine application. $17^{\text {th }}$ International Symposium on Airbreathing Engines, September 4-9 2005 Munich Germany Paper No ISABE - 2005$1220 \mathrm{http}: / / \mathrm{www} . \mathrm{mtn} . \mathrm{de} / \mathrm{channel/files/pdf}$ noncontact blade vibration pdf 


\section{KONCEPCJA MONITOROWANIA LOPATKI MASZYNY WIRNIKOWEJ Z IDENTYFIKACJA JEJ CZESTOTLIWOŚCI DRGAŃ}

\section{Wstęp}

W procesie użytkowania (pracy) maszyn wirnikowych bardzo ważnym problemem jest monitorowanie (bieżąca ocena) stanu technicznego ich newralgicznych elementów składowych, którymi obok łożysk są łopatki. Praktyka pokazuje, że urwanie się tylko jednej łopatki (z kilkudziesięciu, kilkuset) prowadzi prawie zawsze do poważnej awarii całej (często bardzo kosztownej) maszyny wirnikowej (sprężarki osiowej, turbiny). Stąd wynika duże zainteresowanie metodami bieżącego monitorowania stanu technicznego łopatek podczas ich pracy.

Obecnie stosuje się wiele różnych metod monitorowania stanu technicznego łopatek maszyn wirnikowych. Metody te bazują na tzw. „bezdotykowym” szacowaniu wartości bieżących przemieszczeń wierzchołka łopatki w chwilach gdy znajduje się on w strefie pod czujnikiem. Opracowano wiele „bezdotykowych” systemów pomiarowych (ze specjalizowanym komputerowym oprogramowaniem) do pomiaru i przetwarzania sygnałów działania łopatki podczas pracy maszyny wirnikowej. Są to powszechnie znane i stosowane systemy pomiarowe: wykonane przez firmy: Hood, Agilis, Prat\&Whithey (USA), Rolls Royce (UK), ABB Turbocharges (Szwajcaria), MTU (Niemcy), ITWL (Polska), a także firmy rosyjskie, chińskie i indyjskie $[1,3,4,5,6,7,8,9,10,11,16,18,19,20]$.

Dotychczasowe metody monitorowania stanu technicznego łopatek bazują tylko na przetwarzaniu zmierzonych sygnałów wynikających $\mathrm{z}$ działania łopatek, bez wystarczającego uwzględnienia jej zmiennego otoczenia, co zapewne wynika z faktu, że pomiar zmiennego otoczenia łopatki (zmienne: temperatura, ciśnienie, siły odśrodkowe, momenty zginające i skręcające; siły mocujące łopatkę w zamku) jest bardzo trudny a często niemożliwy. Zatem należy stwierdzić, że metody te nie realizują w pełnym stopniu podstawowej zasady diagnostyki technicznej nakazującej badanie i analizę stanu technicznego obiektu $\mathrm{z}$ uwzględnieniem wpływu otoczenia i właśnie z tego względu nie są one wystarczająco dokładne.

Dotychczas proponowane metody diagnostyczne nie dają bezpośredniego przełożenia na podstawowe mierzalne parametry procesu drganiowego. Pojawiła się zatem potrzeba opracowania nowej metody monitorowania stanu technicznego łopatki w czasie rzeczywistym $\mathrm{z}$ uwzględnieniem jej otoczenia, ale bez pomiaru niedostępnych, często niemierzalnych sygnałów otoczenia.

Problem ten aktualnie jest rozwiązywany poprzez dwukrotne identyczne pobudzanie łopatki do drgań (diagnozowanie statyczne)[12, 14 ] lub badanie ruchu wierzchołka łopatki w dwóch różnych okresach obserwacji (diagnozowanie dynamiczne) $[5,6,15]$. 
The concept of monitoring blades of rotor machines with the identification... Koncepcja monitorowania łopatki maszyny wirnikowej z identyfikacja...

Stad pojawiła się nowa metoda monitorowania stanu technicznego łopatki w czasie pracy, bazująca na pomiarze parametrów ruchu wierzchołka łopatki zrealizowanym za pomocą kaskady składającej się z 3 indukcyjnych czujników prędkości chwilowej (odpowiednio mało względem siebie przesuniętych).

Metoda daje szerokie możliwości analizy zdeterminowanej i statystycznej prowadzące do wyznaczenia podstawowego parametru procesu drganiowego, którym jest częstotliwość drgań łopatki, pozwalającym na określenie zmian stanu technicznego łopatki.

\section{Lopatka podczas pracy $\mathbf{w}$ zmiennym otoczeniu}

Łopatkę podczas pracy w zmiennym otoczeniu przedstawiono na rys. 1.
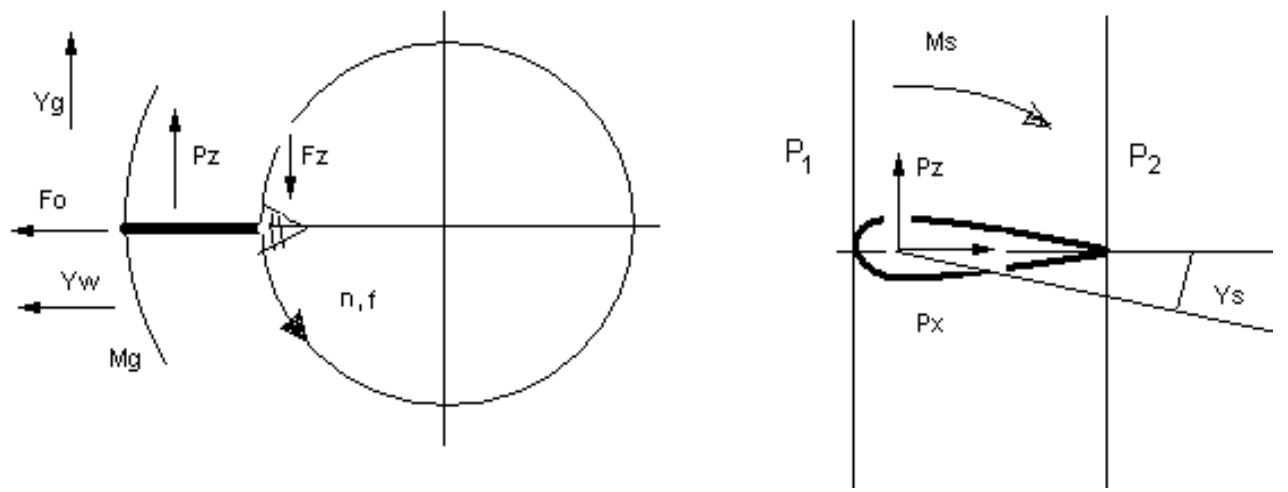

Rys. 1 Lopatka maszyny wirnikowej w zmiennym otoczeniu.

$F_{o}$ - sita odśrodkowa; $F_{z}$ - sita zacisku zamka; $n$-prędkość obrotowa; $P_{z}-$ aerodynamiczna sita nośna topatki; $P_{x^{-}}$siła oporu; $M_{s^{-}}$moment skręcajacy; $M_{g}$ - moment zginajacy; $p_{l^{-}}$ciśnienie gazu na wejściu wieńca wirnika; $p_{2}$ - ciśnienie gazu na wyjściu wieńca wirnika; $Y_{g}$ - ugięcie topatki; $Y_{s}$ - kat skręcenia topatki; $Y_{w^{-}}$przemieszczenie wzdlużne topatki; $f$ - sygnat różnych postaci drgań (zginajace, skręcające, wzdluzine)

Z rys.1 widać, że łopatka jest konstrukcyjnie stosunkowo prostym obiektem technicznym lecz o złożonym stanie działania, znajdującym się w wielowymiarowym zmiennym otoczeniu. Stan działania łopatki opisuje mierzalny sygnał przemieszczenia wierzchołka łopatki $y(t)$, który jest wynikiem działania sygnałów $\left(Y_{g}, Y_{w}, Y_{s}, f\right)$, a jej otoczenie opisuje wielowymiarowy sygnał $x(t)$, który jest wynikiem działania sygnałów $\left(n, F_{0}, P_{z}, P_{x}, p_{1}, p_{2}, F_{z}, f\right)$. Stan techniczny łopatki $A(\Theta)$ wynika z relacji między sygnałem $y(t)$ i $x(t)$ w chwili aktualnego diagnozowanego $\Theta_{1}$ i chwili początku diagnozowanego $\Theta_{0}$. 
Zatem można zapisać $[13,15]$ :

$$
A(\Theta)=f\left(y(t)_{\Theta_{0}}, x(t)_{\Theta_{0}}, y(t)_{\Theta_{1}}, x(t)_{\Theta_{1}}\right.
$$

gdzie:

$A(\Theta)$ - macierz parametrów stanu technicznego łopatki,

$\mathrm{t}$ - czas newtonowski (badań diagnostycznych),

$\Theta$ - czas bergsonowski (wnioskowania diagnostycznego).

Współczynniki charakteryzujące stan techniczny łopatki $A(\Theta)$ oraz sygnały deterministyczne $y(t)$ i sygnału $x(t)$ po transformacji występują transmitancji widmowej :

$$
G(j \omega)=\frac{Y(j \omega)}{X(j \omega)}=\frac{\sum_{i=0}^{m} b_{i}(j \omega)^{i}}{\sum_{i=0}^{n} a_{i}(j \omega)^{i}}=\frac{S_{x y}}{S_{x x}}
$$

oraz w funkcji określającej kwadrat wzmocnienia amplitudowego $W^{2}$ i przesunięcia fazowego $\varphi$ sygnału $y(t)$ względem sygnału otoczenia $x(t)$ :

$$
\begin{gathered}
\varphi=\operatorname{Arg} G(j \omega)=\operatorname{Arg} \frac{\sum_{i=0}^{m} b_{i}(j \omega)^{i}}{\sum_{i=0}^{m} a_{i}(j \omega)^{i}}=\operatorname{Arg} \frac{S_{x y}}{S_{x x}} \\
W^{2}=|G(j \omega)|^{2}=\frac{\sum_{i=0}^{m} b_{i}(j \omega)^{i}}{\sum_{i=0}^{n} a_{i}(j \omega)^{i}}=\left|\frac{S_{x y}}{S_{x x}}\right|^{2}=\frac{S_{y y}}{S_{x x}}
\end{gathered}
$$

gdzie:

$G(j \omega)$ - transmitancja widmowa,

(j $\omega) \quad-$ częstość urojona zmiennej zespolonej $s$,

$S_{x y}, S_{y y}, S_{x x}$ - funkcje gęstości widmowej wzajemnej i własnej mocy sygnałów $y(t)$ i $x(t)$.

Wyrażenia matematyczne (3) i (4) mogą być modelami diagnostycznymi badanego obiektu technicznego. Wiążą bowiem sygnały działania obiektu $y(t)$ i sygnały otoczenia $x(t)$ z parametrami stanu technicznego $A(\Theta)[2,12,14,15,16,17]$. $\mathrm{W}$ proponowanym rozwiązaniu układu pomiarowego mamy do czynienia $\mathrm{z}$ trzema czujnikami pomiarowymi rozstawionymi w niewielkiej znanej odległości $\Delta L$. 
The concept of monitoring blades of rotor machines with the identification... Koncepcja monitorowania topatki maszyny wirnikowej z identyfikacja...

Zatem mamy:

$$
\begin{aligned}
& W_{(1)}^{2}=\frac{S_{y y}^{(1)}}{S_{x x}^{(1)}} ; \quad W_{(2)}^{2}=\frac{S_{y y}^{(2)}}{S_{x x}^{(2)}} ; \quad W_{(3)}^{2}=\frac{S_{x y}^{(3)}}{S_{x x}^{(3)}} ; \\
& \varphi_{(1)}=\operatorname{Arg} \frac{S_{x y}^{(1)}}{S_{x x}^{(1)}} ; \varphi_{(2)}=\operatorname{Arg} \frac{S_{x y}^{(2)}}{S_{x x}^{(2)}} ; \varphi_{(3)}=\operatorname{Arg} \frac{S_{x y}^{(3)}}{S_{x x}^{(3)}}
\end{aligned}
$$

Z faktu że czujniki rozstawione są w niewielkiej odległości, to można założyć, że otoczenie reprezentowane przez sygnały $x(t)$ jest stałe wtedy mamy:

$$
S_{x x}^{(1)}=S_{x x}^{(2)}=S_{x x}^{(3)} .
$$

Dalej możemy utworzyć nowe modele diagnostyczne, które są niezależne od otoczenia w postaci odpowiednich ilorazów wzmocnień amplitudowych:

$$
\begin{aligned}
& W_{(1,2)}^{2}=\frac{\frac{S_{y_{1} y_{1}}^{(1)}}{S_{x_{1} x_{1}}^{(1)}}}{\frac{S_{y_{y_{1}} y_{2}}^{(2)}}{S_{x_{2} x_{2}}^{(2)}}}=\frac{S_{y_{y_{1}}}^{(1)}}{S_{y_{2} y_{1}}^{(2)}} \\
& W_{(2,3)}^{2}=\frac{\frac{S_{y_{2} y_{2}}^{(2)}}{S_{x_{2} x_{2}}^{(2)}}}{\frac{S_{y_{3} y_{3}}^{3)}}{S_{x_{3} x_{3}}^{(3)}}}=\frac{S_{y_{2} y_{2}}^{(2)}}{S_{y_{3} y_{3}}^{(3)}}
\end{aligned}
$$

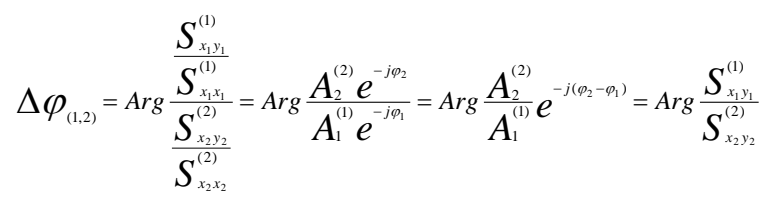

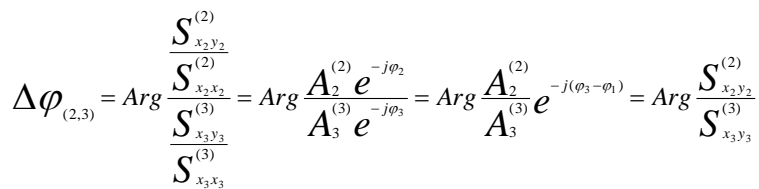

$W_{(12)}^{2}$ - wzmocnienie amplitudowe $\mathrm{z}$ sygnału czujnika 1 względem sygnału z czujnika 2

$S_{y_{y_{1}}}^{(1)} S_{y_{2} y_{2}}^{(2)}$ - gęstość widmowa własna mocy sygnału y z czujnika 1 i z czujnika 2

$S_{x_{x_{1}}}^{(1)} S_{x_{2} x_{2}}^{(2)}$ gęstość widmowa własna mocy sygnału otoczenia x z czujnika 1 i z czujnika 2 
$W_{(23)}^{2}$ - wzmocnienie amplitudowe $\mathrm{z}$ sygnału czujnika 2 względem sygnału z czujnika 3

$S_{y_{3} y_{3}}^{(3)}, S_{y_{2} y_{2}}^{(2)}$ - gęstość widmowa własna mocy sygnału y z czujnika 3 i z czujnika 2

$S_{x_{3} x_{3}}^{(3)}, S_{x_{2} x_{2}}^{(2)}$ - gęstość widmowa własna mocy sygnału otoczenia x z czujnika 3 i z czujnika 2

$\Delta \varphi_{(1,2)}=\varphi_{(1)}-\varphi_{(2)}-$ różnica przesunięcia fazowego sygnału y względem sygnału $\mathrm{x}$ z czujnika (1) i (2)

$\Delta \varphi_{(2,3)}=\varphi_{(3)}-\varphi_{(2)} \quad$ - różnica przesunięcia fazowego sygnału y względem sygnału $\mathrm{x}$ z czujnika (3) i (2)

$S_{x y}^{(2)}, S_{x y}^{(3)}$ - gęstość widmowa wzajemna mocy sygnału y z czujnika 2 i czujnika 3 i ich otoczenia $x$.

Modele $7 \div 10$ posiadają tę cechę, że nie wymagają pomiaru otoczenia $\mathrm{x}$.Wzory 9 i 10 zawierają sygnał otoczenia $\mathrm{x}$ ale może ono być dowolnie przyjętą dystrybucją $\delta(t, \tau)$ bo iloraz gęstości widmowych wzajemnych sygnałów x i y nie zależy od postaci sygnału $x[2,5,17]$

\section{Metoda monitorowania stanu technicznego lopatki na podstawie obserwacji częstotliwości z wyrażeń $W_{i j}^{2}$ i $\varphi_{i j}$}

Metoda monitorowania zmian stanu technicznego łopatki maszyny wirnikowej bazująca na obserwacji częstotliwości obliczonej z wyrażeń $W_{i j}^{2}$ i $\varphi_{i j}$ wyznaczonych podczas przejścia wybranej łopatki kolejno pod trzema czujnikami. Ich znamienną cechą jest to, że ustalony czas na przykład $T_{(1)}$ rys. 2 . przemieszczania się łopatki $y(t)$ pod czujnikiem (1) jest znany i pozwala na wyznaczenie chwilowej prędkości poruszania się łopatki pod czujnikiem. Tak samo wyznaczymy kolejne prędkości chwilowe poruszania się łopatki pod kolejnymi czujnikami (2) i (3). Przykładowy sygnał powstający podczas przemieszczania się łopatki pod czujnikiem z różnymi czasami obserwacji $T_{d}$ i $T_{(1)}$ przedstawiono na rys. 2.

Na rys. 3 przedstawiono rzeczywiste sygnały z trzech czujników indukcyjnych kaskady dla kolejnych łopatk turbiny parowej, oraz sygnały kaskady dla wybranej jednej łopatki. Na rys. 4 przedstawiono wybrane sygnały z 3 czujników kaskady dla wybranej łopatki oraz te same sygnały po normalizacji . 
The concept of monitoring blades of rotor machines with the identification... Koncepcja monitorowania łopatki maszyny wirnikowej z identyfikacja...

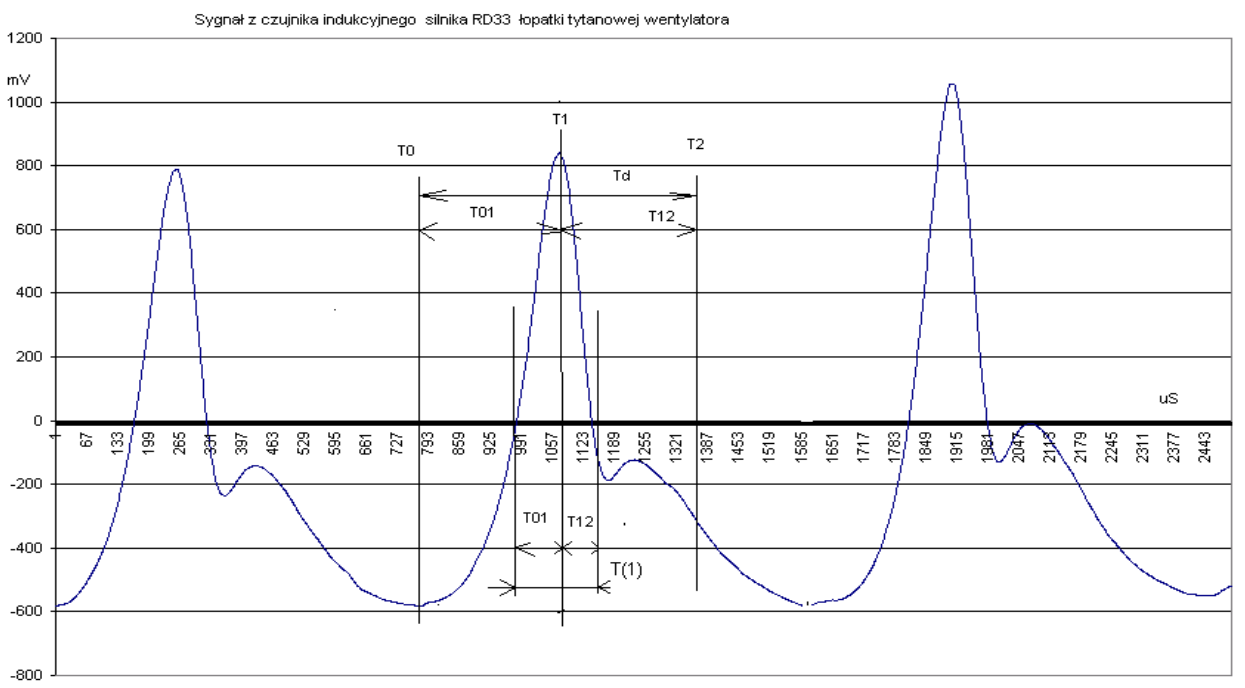

Rys. 2 Sygnat z czujnika indukcyjnego od przechodzacych topatek

$T_{d}$,- dlugi okres obserwacji przebywania wierzchotka topatki w strefie czujnika,

$T_{(1)}$ - krótki okres obserwacji przebywania wierzchotka topatki $w$ strefie czujnika, dla kolejnych czujników $T_{(2)} T_{(3)}$,

$T_{0}, T_{1}, T_{2}$ - charakterystyczne chwile obserwacji wierzchotka topatki pod czujnikiem,

$T_{01}, T_{12}$ - podokresy obserwacji wierzchotka topatki

- sygnat od przemieszczania wierzchotka topatki - $m V$,

- czas przemieszczania łopatki- $u S$

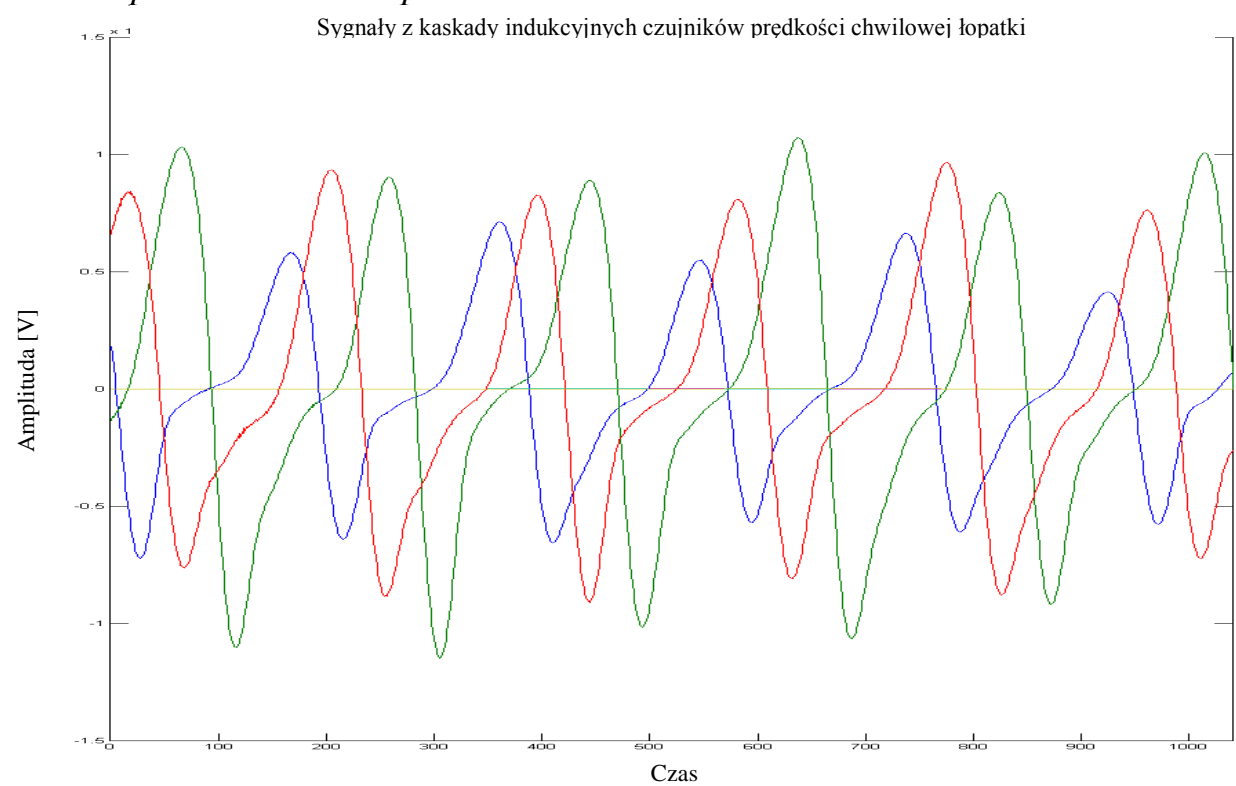


Edward Rokicki, Pawet Lindstedt, Jerzy Manerowski, Jarosław Spychata

Rys. 3 Rzeczywiste sygnaty kaskady czujników z maszyny wirnikowej
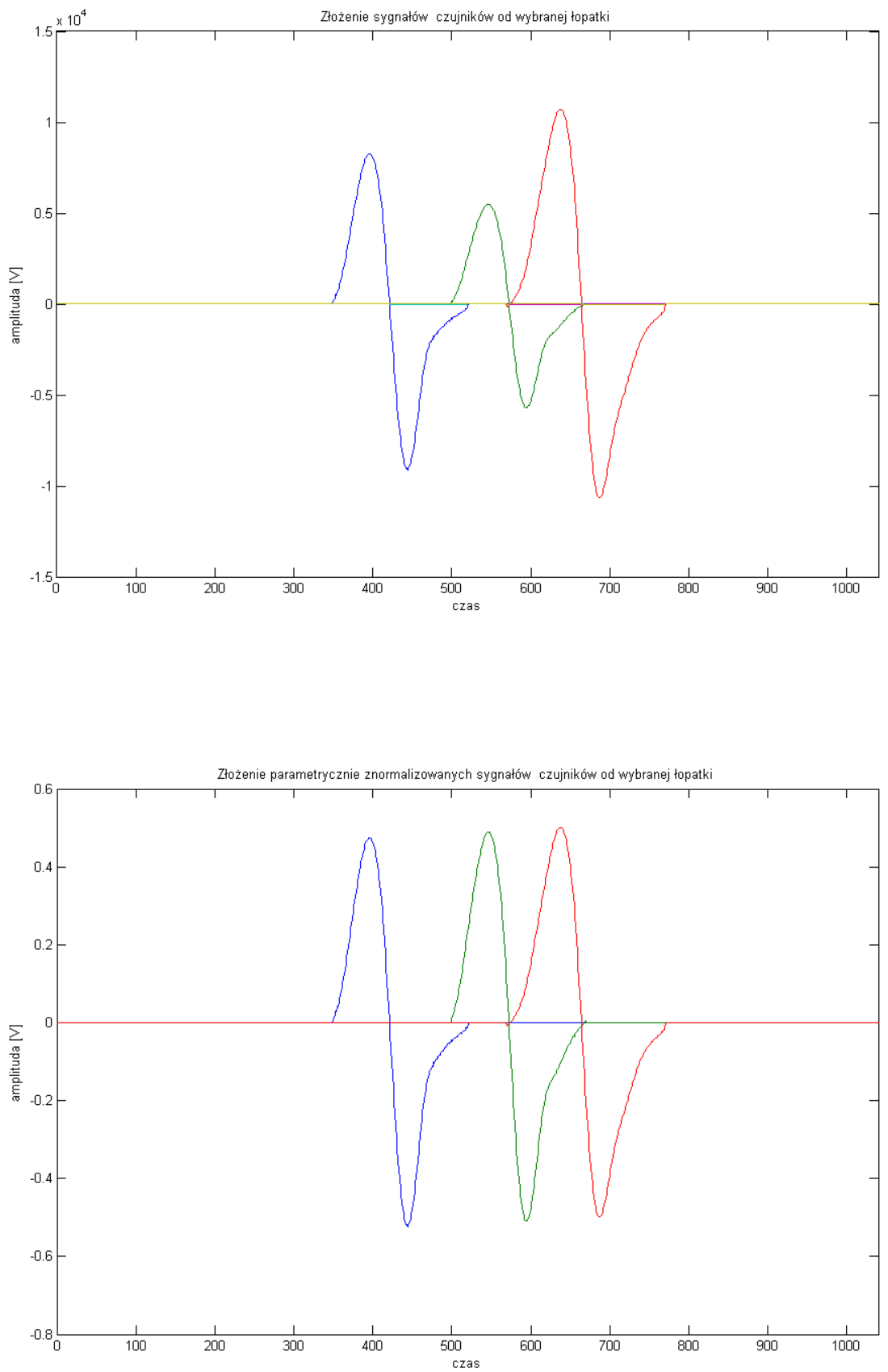

Rys. 4 Wybrane rzeczywiste sygnały kaskady czujników z maszyny wirnikowej oraz sygnaty po kalibracji parametrycznej 
The concept of monitoring blades of rotor machines with the identification... Koncepcja monitorowania topatki maszyny wirnikowej z identyfikacja...

Następnie dla sygnałów $y_{(1)}(t), y_{(2)}(t), y_{(3)}(t)$ w założonych przedziałach obserwacji $T_{(1)}, T_{(2)}, T_{(3)}$ wyznacza się estymaty funkcji autokorelacji $R_{y_{1} y_{1}}^{* *_{(1)}}$ i $R_{y_{2} y_{2}}^{* *_{(2)}}$ i $R_{y_{3} y_{3}}^{* T_{(3)}}$ oraz korelacji wzajemnej $R_{x y_{1}}^{* \pi_{(1)}} R_{x y_{2}}^{* T_{(2)}} R_{x y_{3}}^{* T_{(3)}}$ i dopasowuje do nich odpowiednie wyrażenia analityczne $[2,12,13,14,17]$ :

Dla czujników 1, 2, 3 mamy :

$$
R_{y_{k} y_{k}}^{\left.(k) T_{k}\right)} \cong \sum_{i=0}^{m} \alpha_{i T_{(k)}} e^{-\beta \pi_{(k)} \tau} \cos \left(\gamma_{\pi^{\prime}(k)} \tau\right)
$$

gdzie:

$\mathrm{k}=(1),(2),(3)$ kolejny czujnik

$\alpha_{i T_{(1)}} \beta_{i T_{(1)}} \gamma_{i T_{(1)}}$ - parametry analitycznej postaci funkcji korelacji,

$\tau$ - czas przesunięcia (zmienna przestrzeni funkcji korelacji),

m - liczba składników funkcji korelacji.

Funkcja korelacji wzajemnej sygnału wyjściowego $y(t)$ z dystrybucją sygnału wejściowego $x(t)=\delta(t, \tau)$

$$
\boldsymbol{R}_{\delta_{\delta_{(k)}}^{(k) T_{k}}}^{()_{i}}=\sum_{i=0}^{m} \alpha_{i T_{(k)}} e^{-\beta_{T_{(k)}} \tau} \cos \left(\gamma_{\pi_{(k)}} \tau\right)
$$

gdzie:

$\alpha_{i T_{(k)}} \beta_{i T_{(k)}} \gamma_{{ }^{T}(k)}$ - parametry analitycznej postaci funkcji korelacji, i kolejnego czujnika;

$\tau$ - czas przesunięcia (różny od czasu dynamicznego t)

$m$ - liczba składników funkcji korelacji.

Funkcje korelacji $R_{y_{y^{\prime} k_{k}}}^{(k) T_{k(k)}}$ i $R_{\left.\delta_{\delta_{k}}\right)}^{(k)}$ są podstawą do wyznaczenia funkcji gęstości mocy sygnałów dla kolejnych czujników

$$
\begin{gathered}
S_{y_{k} y_{k}}^{k}=\mathfrak{I} R_{y_{k} y_{k}}^{(k) T_{(k)}} \\
S_{\partial y_{k}}^{k}=\mathfrak{I} R_{\partial y_{k}}^{(k)}
\end{gathered}
$$

gdzie k numer kolejnego czujnika. 
Wyrażenie [11] i [12] pozwalają wyznaczyć $W_{(12)}^{2} W_{(23)}^{2} \Delta \varphi_{(12)} \Delta \varphi_{(23)}$ (wzory $7 \div 10$ ) które sprowadza się do postaci algebraicznej

$$
\begin{aligned}
& W_{(12)}^{2}=\frac{S_{y_{1, y_{1}}}^{(1)}}{S_{y_{2} y_{2}}^{(2)}}=\frac{\sum_{i=0}^{m} b_{i}^{(1,2)}(s)^{i}}{\sum_{i=0}^{n} a_{i}^{(1,2)}(s)^{i}} \\
& W_{(23)}^{2}=\frac{S_{y_{2, y_{2}}}^{(2)}}{S_{y_{3} y_{3}}^{(3)}}=\frac{\sum_{i=0}^{m} b_{i}^{(2,3)}(s)^{i}}{\sum_{i=0}^{i} a_{i}^{(2,3)}(s)^{i}} \\
& \Delta \varphi_{(12)}=\operatorname{Arg} \frac{S_{\delta, y_{2}}^{(2)}}{S_{\delta, y_{1}}^{(1)}}=\operatorname{Arg} \frac{\sum_{i=0}^{m} L_{n}^{(1,2)}(s)^{i}}{\sum_{i=0}^{n} M_{i}^{(1,2)}(s)^{i}} \\
& \Delta \varphi_{(23)}=\operatorname{Arg} \frac{S_{\delta, y_{3}}^{(3)}}{S_{\delta, y_{2}}^{(2)}}=\operatorname{Arg} \frac{\sum_{i=0}^{m} L_{i}^{(2,3)}(s)^{i}}{\sum_{i=0}^{n} M_{i}^{(2,3)}(s)^{i}}
\end{aligned}
$$

Przy czym $s \equiv j \omega, \omega$ - częstotliwość drgań łopatki między kolejnymi czujnikami Konstrukcyjnie zabezpieczono małe odległości między czujnikami 1, 2, 3. Z tego względu wcześniej założono, że otoczenie $x_{1}(t)=x_{2}(t)=x_{3}(t)$ jest stałe.

Można też założyć na podstawie bliskiego położenia czujników 1 i 2 oraz 2 i 3 że:

$$
\begin{gathered}
\frac{W_{(12)}^{2}}{W_{(23)}^{2}} \cong 1 \\
\Delta \varphi_{(1,2)}-\Delta \varphi_{(2,3)} \cong 0
\end{gathered}
$$

Oznacza to że wzmocnienie amplitudowe między czujnikami 1 i 2 oraz 2 i 3 jest stałe Stały jest też przyrost przesunięcia fazowego. Wzory 17 i 18 pozwalają wyznaczyć częstotliwość drgań łopatki $\omega$ między czujnikami 1, 2 oraz 2, 3 . 
The concept of monitoring blades of rotor machines with the identification... Koncepcja monitorowania topatki maszyny wirnikowej z identyfikacja...

\section{Podsumowanie}

Metoda monitorowania zmian stanu technicznego łopatki jest nowatorską metodą diagnozowania łopatki w otoczeniu bez pomiaru sygnałów otoczenia.

Metoda monitorowania stanu technicznego łopatki bazuje na modelu diagnostycznym $\quad \mathrm{w}$ postaci ilorazu wzmocnień amplitudowych $W_{(12)}^{2}$ i $W_{(23)}^{2}$ przesunięć fazowych $\Delta \varphi_{(12)}$ i $\Delta \varphi_{(23)}$ sygnału wyjściowego $y(t)$ do sygnału otoczenia $x(t)$ dla blisko siebie rozmieszczonych czujników (1), (2), (3). Metoda monitorowania stanu technicznego obiektu znamienna jest tym, że wzmocnienie amplitudowe $W^{2}$ i przesunięcie fazowe między czujnikami nie zmienia się (wzory 17 i 18). Cechą charakterystyczną modelu $W^{2}$ i $\Delta \varphi$ jest także to, że nie wymaga on pomiaru sygnałów otoczenia, chociaż pośrednio jest ono uwzględnione specjalnie zorganizowanymi badaniami diagnostycznymi (kilka okresów obserwacji, kilka pobudzeń, kilka czujników, wyznaczenie modelu diagnostycznego jako ilorazu modeli diagnostycznych wiążących sygnały otoczenia $\mathrm{z}$ parametrami stanu technicznego). W tej metodzie diagnostycznej głównym parametrem diagnostycznym jest częstotliwość drgań łopatki w danej chwili obserwacji łopatki .

\section{Bibliografia}

[1] Bovishanskii K.N. et.al.: A method for continously monitoring the vibrational state of the rotating blades of turbomachines. Thermal engineering (Teploenegetika), Vol 47 No 5 2000. St. Petersburg

[2] Bendat J.S., Piersol A.G.: Metody analizy i pomiaru sygnałów losowych. PWN, Warszawa 1976

[3] Duan F., Fang Z., Sun Y., Ye S.: Real-time vibration measurement technique based on tip - timing for rotating blades. Opto-Electronic Energineering 200530 (1) 29-31 htt://www.paper.edu.cn

[4] von Flotow A., Mercadal H.: Turbine rotor health management with bladetip sensors; From Laboratory Tool To Fielded System. www hoodtech tlood River or USD 2000

[5] Grądzki R. Parametryczne modele diagnostyczne łopatki pracującej maszyny wirnikowej $\mathrm{z}$ eliminacją niemierzalnych sygnałów otoczenia. Rozprawa doktorska. Politechnika Białostocka Białystok 2012 
[6] Grądzki R. Borowczyk H. Lindstedt P. Parametryczna metoda diagnozowania maszyny wirnikowej z eliminacją niemierzalnych czynników otoczenia.Tom 8.Problemy Badań I Eksploatacji Techniki Lotniczej. Wyd. ITWL Waeszawa 2012

[7] High Cycle Fatigue S \& program 1999 Annual Report http://stimet.dtic.mil

[8] High Cycle Fatigue S \& program 2000 Annual Report http://stimet.dtic.mil

[9] High Cycle Fatigue S \& program 2001 Annual Report http://stimet.dtic.mil

[10] High Cycle Fatigue S \& program 2002 Annual Report http://stimet.dtic.mil

[11] Klein B.: Non-Contact Vibration measurements Turbocharges Turbine and Compressor Blades. Proceedings of $1^{\text {st }}$ EVI-GTI International Conference on Gas Turbine Instrumentation, Barcelona 2004

[12] Kotowski A., Lindstedt P.: The using of signals of impulse acoustic response in tests of rotor blades in stationary conditions. The International Symposium on Stability Control of Rotating Machinery. ISCORMA 4, Calgary Alberta Canada 2007

[13] Kurowski W.: Podstawy teoretyczne komputerowego miernictwa systemów mechanicznych. Wyd. Politechniki Białostockiej, Białystok 1994

[14] Lindstedt P., Kotowski A.: Basics for innovations in vibroacoustic diagnostics of transport machines rotor blades. The Archives of Transport Vd XVI No4 2004

[15] Lindstedt P. Grądzki R. : Diagnosis in a working rotor machine employing the method virtual elimination of statistic environment. The Archive of Mechanical Engineering. Vol LVIII2013,3 Warsaw.

[16] Roberts J.P.: Comparison of Tip Timing with strain ganges for rotor blade vibration measurement. Proceedings of lecture series on Tip Timing an Tip Clearnce Problems in Turbomachines Von Karman Instytute Belgium 2007

[17] Szabatin J.: Podstawy teorii sygnałów, WKŁ Warszawa 2000,

[18] Szczepanik R., Przysowa R.: Wykonanie badań i pomiarów drgań łopatek metodą bezstykową $\mathrm{W}$ odwirowni ALSTOM Power $\mathrm{w}$ Elblągu. Sprawozdanie ITWL nr 36/3 /2004 Warszawa 2004

[19] Washburn R. S.: A State of The Art PC based NSMS Analysis Software Package. http;//www.agilismeasurementsystems.com

[20] Zieliński M., Ziller G.: Non-contact Blade Vibration measurement system for aero engine application. $17^{\text {th }}$ International Symposium on Airbreathing Engines, September 4-9 2005 Munich Germany Paper No ISABE - 20051220 http://www.mtn.de/channel/files/pdf noncontact blade vibration pdf 
The concept of monitoring blades of rotor machines with the identification... Koncepcja monitorowania łopatki maszyny wirnikowej z identyfikacja...

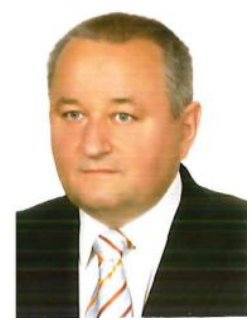

Dr inż. Edward Rokicki adiunkt, pracownik Zakładu Silników Lotniczych ITWL. Uczestniczy $w$ opracowaniu nowoczesnych systemów diagnostycznych stanu technicznego turbin silników odrzutowych oraz turbin energetycznych. Jest wspóttwórca siedmiu polskich patentów, oraz dwóch patentów amerykańskich. Odznaczony przez Komisję Odznaczeń Belgii ds. Wynalazczości Krzyżem Oficerskim Orderu Wynalazczości.

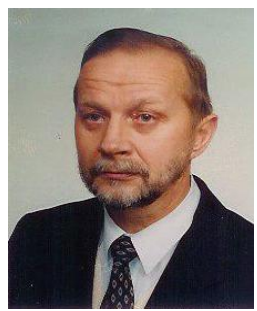

Prof. dr hab. inż Pawet Lindstedt, Profesor zwyczajny Instytutu Technicznego Wojsk Lotniczych. Tematyka badawcza: budowa $i$ eksploatacja maszyn, automatyka stosowana, diagnostyka $i$ niezawodnośc urządzeń technicznych. Jego prace skupiaja się głównie na zagadnieniach zwiazanych $z$ diagnostyka silników lotniczych, systemów hydraulicznych, diagnostyce wibroakustycznej i procesach zużcia. (Udziat 33\%)

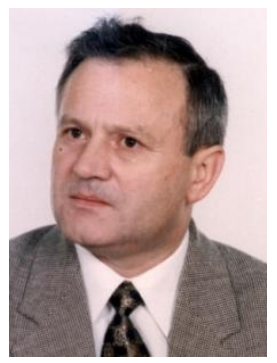

Prof. dr hab. inz. Jerzy Manerowski - Profesor zwyczajny, Politechnika Warszawska, Wydziat Transportu; Instytut Techniczny Wojsk Lotniczych; dyscyplina - mechanika, budowa i eksploatacja maszyn, transport; czlonek Centralnej Komisji ds. Stopni i Tytułów; członek Wydziału IV Nauk Technicznych Komitet Transportu Polskiej Akademii Nauk. Obszary badawcze: identyfikacja i modelowanie dynamiki lotów statków powietrznych z wykorzystaniem sztucznych sieci neuronowych.

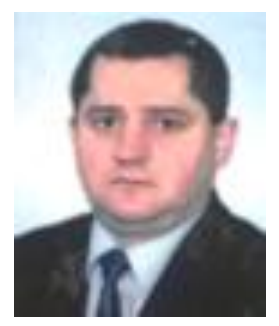

Dr inz. Jaroslaw Spychala jest absolwentem Wojskowej Akademii Technicznej (1987) - specjalność samoloty $i$ śmigłowce. Prace w ITWL rozpoczą w 1988 r. Od 2004 r. w ITWL petni funkcję kierownika Zakładu Silników Lotniczych. 